\title{
China's Standards of English and Its Applications in English Teaching and Testing on Visually Impaired College Students*
}

\author{
ZHENG Yu-rong \\ Changchun University, Changchun, China
}

\begin{abstract}
China's Standards of English (CSE) issued by The Ministry of Education Examination Center in June 2018, is mainly used to guide language assessment, and also provides a reference for English language learning and teaching. Based on the assessment results of the visually impaired students' English proficiency using the self-evaluation Level 5 subscale, we can use the scale to implement language proficiency assessment, and can diagnose the English teaching and learning of visually impaired students. It is recommended that the results of the scale assessment be used to strengthen the construction of English courses for visually impaired students, to improve the teaching content and strategies, and implement the process evaluation methods. Students can enhance self-learning and personalized learning based on self-assessment results.
\end{abstract}

Keywords: self-evaluation, visually impaired students, China’s Standards of English, college English teaching

\section{Introduction to China's Standards of English (CSE)}

China's Standards of English Language Ability as National Language Standard was implemented on 1 June, 2018 by Ministry of Education of the People's Republic of China and National Language Commission of the People's Republic of China, hereinafter referred to as the CSE. Its groundbreaking significance is unquestionable-China's first national standard for English proficiency assessment. CSE focuses on the core of language use in the vertical direction, dividing the learner's English ability from low to high into nine competency levels. Each of three levels corresponds to three general stages of the beginning, the middle, and the high. In the horizontal direction, the CSE builds a complete English ability description framework, covering language comprehension (i.e., listening, reading), language production skills (i.e., speaking, writing), translation skills, language knowledge, and language use strategies, among which the scales on interpreting ability, translation ability, and pragmatic ability are references that the learners did not have in the past. After a comprehensive, clear, and detailed description of the capabilities of each level, CSE also provides a self-evaluation scale to facilitate language learners and users to judge and diagnose their English proficiency. Self-evaluation subscale includes self-evaluation in terms of organizational knowledge, listening comprehension, written comprehension, verbal communication, written expression, pragmatic competence, interpreting ability, and translation ability. As early as CES being under the development, Liu Jian-da (2015a, p. 8) pointed out that the CSE will be widely applicable to various English learners and users. Scholars expect that

\footnotetext{
* This paper is the phased research results of the 2018 Jilin Province Educational Department Thirteenth Five-Year Social Sciences Research "Study on the Practice of the English as a Minor Major of Visually Impaired College Students in Inclusive Classes” (Project Number: 2018LY503w12).

ZHENG Yu-rong, master, lecturer, Foreign Language College, Changchun University, Changchun, China.
} 
the application prospects of the CSE can cover the planning and adjustment of policy formulation, curriculum construction, designs on teaching and learning objectives, syllabus, textbook content, exam evaluation, teaching and learning strategies.

Before the introduction of the CSE, to decide whether the educational goals of the ability in various tests are achieved, researchers generally adopt the level of competence according to Benjamin Bloom's taxonomy. The cognitive ability pyramid from low to high was memorizing and understanding the low-level, application and analysis the middle-level and evaluation and creativity the high level (Anderson, 2009). The current foreign English proficiency rating scales such as the European Language Framework's (Council of Europe, 2001) descriptor "can-do statement" is adopted by the CSE to define language proficiency. "Can do" or "I can" starts from the learner's capability, focusing attention on whether or not learning occurs, effective and meet the standard. According to the current situation of English education in China, Wang Shou-ren (2018, p. 3) believes that the "improvement" stage (Grade 4-6) of the intermediate users of the CSE is highly compatible with college English learners in China, and may also include the high school education stage and the lower grades of English major learner. When talking about the future impact of the scale, Zen Yong-qiang (2017, p. 10) predicts that the CSE is a "bridge" for learning, teaching, and evaluation; it is a "ruler" for assessing the effectiveness of learning and teaching; it is a "Mold" for test developing and textbook composition. This paper attempts to use the eight self-evaluation subscales provided by the CSE to explore some of the problems of visually impaired college students in the practice of English classes.

\section{Investigation and Analysis Based on the Self-Evaluation Subscale of CSE}

\section{Questionnaire Content}

According to the scholars' interpretation of the scale, the intermediate Level 4-6 of the CSE is highly relevant to the college English teaching objectives and tests. We extracted 4-6 levels of intermediate coverage from the vertical eight levels of self-evaluation subscale, and made a self-evaluation questionnaire of college English. Horizontally, self-assessment scales include eight subscales, which are organizational competence (Table 79), listening comprehension (Table 80), reading comprehension (Table 81), oral expression (Table 82), written expression (Table 83), pragmatic ability (Table 84), interpreting ability (Table 85), and translation ability (Table 86).

\section{Investigation and Research Methods}

The English level and ability of visually impaired students who are studying in college English classes are obviously different from those of healthy students. The visually impaired students themselves also have different English comprehension and application ability. Visually impaired students here refer to students whose visual acuity has different degrees of damage or loss. They are individuals with low vision but not totally blind, and can participate in a natural class study in a university with the help of related auxiliary facilities. In this study, we used a self-evaluation scale questionnaire for visually impaired students and healthy students to conduct a comparative study. We selected two college English classes that incorporate visually impaired students. There are five visually impaired students and 30 healthy students in Business Class A and Business Class B. In order to increase the validity of the survey and evaluation, we have added two non-integrated teaching classes, namely, the liberal arts C class and the science D class. A total of 124 electronic self-evaluation questionnaires were provided for the above four college English classes, and 90 
healthy students’ questionnaires were collected after voluntary filling. The recovery rate was $73 \%$. All the 10 visually impaired students who participated in the survey submitted the questionnaire.

\section{Self-Evaluation Survey Results Analysis}

The visually impaired students enter the inclusive classroom through the entrance examinations independently organized by the university, and their English level is generally lower than the healthy students. Through rough screening, we abandoned the level 6 self-evaluation results, and only retained the 4th and 5th parts which show obvious differences. The interpretation and translation subscales are described starting from the 5th level, without descriptions of the 4th level and lower corresponding ability being made in CSE. Therefore, the results of this research only select the results of Top 6 items horizontally (Table 79-Table 84) and the vertical Levels 4 and 5 . The results of visually impaired students and healthy students are compared.

Table 1

Self-Assessment Scale for Organizational Competence

\begin{tabular}{|c|c|c|c|c|c|c|c|c|c|}
\hline Table & subscale & 79.4 .1 & 79.4 .2 & 79.4 .3 & 79.4 .4 & 79.5.1 & 79.5.2 & 79.5.3 & 79.5.4 \\
\hline $\begin{array}{l}\text { "Can do" } \\
\text { percentage }\end{array}$ & $\begin{array}{l}\text { visually impaired } \\
\text { students }\end{array}$ & $50 \%$ & $40 \%$ & $80 \%$ & $80 \%$ & $60 \%$ & $50 \%$ & $40 \%$ & $80 \%$ \\
\hline "Can do" & healthy student & $64 \%$ & $47 \%$ & $79 \%$ & $82 \%$ & $66 \%$ & $51 \%$ & $61 \%$ & $62 \%$ \\
\hline
\end{tabular}

Notes. The self-evaluation subscale of the organizational knowledge ability is the Table 79 in the SCE; there are four items of the Level 4 descriptors; the table is recorded as 79.4.1-79.4.4; other language understanding and expression ability modules in the following discussion are indicated in the same way.

Of the four descriptors of the Level 5 on organizational competence (Table 79), the comparative analysis of the data shows that the third item is where major difference can be found, as indicated below:

79.5.3 I can use cohesive devices to express comparison and contrast, cause and effect, progression, and transition with coherence and logic. For the above item descriptor, only $40 \%$ of visually impaired students can do it, and $61 \%$ of healthy students can do it.

Table 2

Self-Assessment Scale for Listening Comprehension

\begin{tabular}{|c|c|c|c|c|c|c|c|}
\hline Table & subscale & 80.4 .1 & 80.4 .2 & 80.4 .3 & 80.5 .1 & 80.5 .2 & 80.5 .3 \\
\hline $\begin{array}{l}\text { "Can do" } \\
\text { percentage }\end{array}$ & $\begin{array}{l}\text { visually impaired } \\
\text { students }\end{array}$ & $70 \%$ & $90 \%$ & $30 \%$ & $30 \%$ & $30 \%$ & $60 \%$ \\
\hline $\begin{array}{l}\text { "Can do" } \\
\text { percentage }\end{array}$ & healthy student & $81 \%$ & $93 \%$ & $64 \%$ & $72 \%$ & $64 \%$ & $74 \%$ \\
\hline
\end{tabular}

For the descriptor 80.4.3 I can understand debates on familiar topics when articulated clearly; and identify main arguments and supporting evidence on both sides, and descriptor 80.5 .2 I can understand the cultural connotations of expressions when communicating with native English speakers on general topics, only $30 \%$ of visually impaired students can do it, and $64 \%$ of healthy students can do it.

Table 3

Self-Assessment Scale for Reading Comprehension

\begin{tabular}{|c|c|c|c|c|c|c|c|c|c|}
\hline Table & subscale & 81.4 .1 & 81.4 .2 & 81.4 .3 & 81.4 .4 & 81.5 .1 & 81.5 .2 & 81.5 .3 & 81.5 .4 \\
\hline $\begin{array}{l}\text { "Can do" } \\
\text { percentage }\end{array}$ & $\begin{array}{l}\text { visually impaired } \\
\text { students }\end{array}$ & $70 \%$ & $90 \%$ & $50 \%$ & $70 \%$ & $60 \%$ & $40 \%$ & $20 \%$ & $60 \%$ \\
\hline $\begin{array}{l}\text { "Can do" } \\
\text { percentage }\end{array}$ & healthy student & $94 \%$ & $90 \%$ & $69 \%$ & $63 \%$ & $78 \%$ & $29 \%$ & $61 \%$ & $72 \%$ \\
\hline
\end{tabular}


For the descriptor 81.5.3 I can extract the key information in practical forms of writing (e.g., memos or notes), while only $20 \%$ of visually impaired students can do it, $61 \%$ of healthy students can do it.

Table 4

Self-Assessment Scale for Oral Expression

\begin{tabular}{lllllllllll}
\hline Table & subscale & 82.4 .1 & 82.4 .2 & 82.4 .3 & 82.4 .4 & 82.4 .5 & 82.5 .1 & 82.5 .2 & 82.5 .3 & 82.5 .4 \\
\hline $\begin{array}{l}\text { "Can do" } \\
\text { percentage }\end{array}$ & $\begin{array}{l}\text { visually impaired } \\
\text { students }\end{array}$ & $50 \%$ & $90 \%$ & $30 \%$ & $50 \%$ & $0 \%$ & $50 \%$ & $70 \%$ & $60 \%$ & $50 \%$ \\
$\begin{array}{l}\text { pan do" } \\
\text { percentage }\end{array}$ & healthy student & $71 \%$ & $83 \%$ & $66 \%$ & $79 \%$ & $53 \%$ & $73 \%$ & $70 \%$ & $70 \%$ & $72 \%$ \\
\hline
\end{tabular}

For the descriptor 82.4.5 I can respond to others appropriately in everyday communication (e.g., daily conversation and talk), using strategies such as repetition, code-switching between Chinese and English, or literal translation to confirm the understanding is correct, none of the visually impaired students can do it, and $53 \%$ of healthy students can do it.

Table 5

Self-Assessment Scale for Written Expression

\begin{tabular}{llllllllllllllllllll}
\hline Table & subscale & 83.4 .1 & 83.4 .2 & 83.4 .3 & 83.4 .4 & 83.4 .5 & 83.4 .6 & 83.4 .7 & 83.4 .8 & 83.5 .1 & 83.5 .2 & 83.5 .3 & 83.5 .4 & 83.5 .5 & 83.5 .6 & 83.5 .7 \\
\hline $\begin{array}{l}\text { "Can } \\
\text { do" }\end{array}$ & $\begin{array}{l}\text { visually } \\
\text { impaired }\end{array}$ & $60 \%$ & $80 \%$ & $40 \%$ & $60 \%$ & $50 \%$ & $40 \%$ & $70 \%$ & $50 \%$ & $0 \%$ & $50 \%$ & $80 \%$ & $60 \%$ & $90 \%$ & $10 \%$ & $40 \%$ & \\
$\begin{array}{l}\text { percent } \\
\text { age }\end{array}$ \\
"Can
\end{tabular}

For the descriptor 83.4.6 I can write an outline before I start writing, only $40 \%$ of visually impaired students can do it, and $80 \%$ of healthy students can do it; for the descriptor 83.5.1 I can write letters to apply $f$ or overseas exchange programs, no one of visually impaired students can do it, and merely $9 \%$ of healthy students can do it; and for the following 83.5.6 I can write short argumentative essays following academic conventions, only $10 \%$ of visually impaired students can do it, and $33 \%$ of healthy students can do it.

Table 6

Self-Assessment Scale for Pragmatic Ability

\begin{tabular}{|c|c|c|c|c|c|c|c|}
\hline$\overline{\text { Table }}$ & subscale & 84.4 .1 & 84.4 .2 & 84.4 .3 & 84.5 .1 & 84.5 .2 & 84.5 .3 \\
\hline $\begin{array}{l}\text { "Can do" } \\
\text { percentage }\end{array}$ & $\begin{array}{l}\text { visually impaired } \\
\text { students }\end{array}$ & $60 \%$ & $70 \%$ & $90 \%$ & $90 \%$ & $60 \%$ & $80 \%$ \\
\hline $\begin{array}{l}\text { "Can do" } \\
\text { percentage }\end{array}$ & healthy student & $73 \%$ & $86 \%$ & $92 \%$ & $80 \%$ & $90 \%$ & $70 \%$ \\
\hline
\end{tabular}

For the descriptor 84.5.2 I can understand formal acknowledgements and use appropriate phrases to express my gratitude, such as "Thanks go first to...”, only 60\% of visually impaired students can do it, and $90 \%$ of healthy students can do it.

\section{CSE and Visually Impaired Students' College English Teaching and Learning}

\section{CSE and Visually Impaired Students English Learning}

The description of the self-evaluation table in CSE “I can” or “can do" highlights the subjective status of 
the learner and advocates that the learner is the main bearer of learning responsibility. Wang Shou-ren (2017, p. 10) pointed out that the self-evaluation scale increases "self-awareness of knowledge and learning". The item by item process of self-evaluation of visually impaired students is a self-control process of knowledge and learning, self-judgment of English ability, and self-test of English level. Finding the advantages and disadvantages of the English ability of visually impaired students, students can make a series of adjustments according to their actual situation after self-positioning, from learning objectives and learning content to learning materials and learning methods. They can gradually go through transition and eventually build self-learning ability

\section{The Scale and the Inclusive English Teaching of Visually Impaired Students}

CSE provides a bridge of communication between English learning, teaching, and testing at all levels. It not only describes the current level of English learners, but also defines the future ability and direction of learners. That is, "both descriptive and prescriptive" (Liu \& Peng, 2017, p. 7). Teachers can make full use of CSE as a powerful tool to improve students' language communication ability from the aspects of college English curriculum construction, teaching strategies, teaching content, and language assessment. CSE also draws on the great achievements of cognitive linguistics. Whether it is describing functions or defining functions, it is in line with the development of cognitive ability in the process of English learning. In the above-mentioned self-evaluation survey of visually impaired students, their weaknesses in the reading and written expression ability scales reflect the lack of high-level competence in cognitive ability. In the classification of cognitive tasks, visually impaired students can only complete low-level recognition and extraction, and at the middle level of generalization and analysis, students can do very little, and it is rare to complete high-level criticism and evaluation. After comparing the strengths of descriptive indicators, English teachers can add modules to guide students to train according to high-level cognitive ability, and strengthen the cultivation of students' critical thinking ability.

Secondly, the most important function of CSE is reflected in the language test. What makes all aspects of the English test in the future from the basis of evidence, test design and content evaluation to test paper analysis, can be based on the scientific system evaluation criteria. The self-evaluation results of visually impaired students suggest that the college English inclusive teaching process can be integrated though, the evaluation process cannot be the same as the health-hearing students. It is necessary to introduce a multi-dimensional evaluation system to conduct an evaluation impartially and objectively to the visually impaired students. In addition to the traditional summative assessment of the final exam, the concept of CSE advocates the use of procedural or formative assessments and provides assessment criteria. In summarizing the formative evaluation, Liu Jian-da (2015b, p. 423) said that "a reciprocal cycle is formed between determining the level of students, determining the goals of students' learning, and determining what students need to do to achieve their goals". Colleges and universities can use the procedural evaluation of English for visually impaired students to replace the summative evaluation used by healthy students in the same class to assess students and promote the development of multiple evaluations.

\section{Conclusion}

The application prospect of CSE is broad, and its function and influence on promoting the scientific, systematic evaluation, and its feedback on teaching are worth looking forward to. This study is only an initial 
attempt to use the self-evaluation subscale in practice, and the practice of inclusive college English education is also like crossing the river by feeling the stones. Visually impaired students and healthy students use the CSE to self-evaluate, which enables students to see where they are, adjust their goals, and promote independent learning and personalized learning. Teachers can improve the syllabus design and adjust the content of the textbook based on the feedback of the self-evaluation results, and even change the traditional summative assessment method, and form a multi-level evaluation system in combination with the process evaluation. The results of this survey also remind policy makers and teachers to work together to change teaching strategies and comprehensively develop students' language comprehension and use ability. This paper expects to sum up experience and provide more reference for the development of visually impaired students' integrated education practice.

\section{References}

Anderson, L. (2009). Bloom education target taxonomy: Learning and teaching from the perspective of taxonomy and its evaluation. Beijing: Foreign Language Teaching and Research Press.

Council of Europe. (2001). Common European framework of reference for languages: Learning, teaching, assessment. Cambridge: Press Syndicate of the University of Cambridge.

Liu, J. D. (2015a). Basic ideas for the development of English proficiency rating scale in China. China Examination, (1), 7-11.

Liu, J. D. (2015b). Exploration of foreign language evaluation based on standards. Foreign Language Teaching and Research, 47(3), 417-425.

Liu, J. D., \& Peng, C. (2017). Constructing a scientific Chinese English proficiency rating scale. Foreign Languages, (2), 2-9.

Ministry of Education of the People's Republic of China and National Language Commission of the People's Republic of China. (2018). China's Standards of English. Beijing: Higher Education Press.

Wang, S. R. (2018). Application of Chinese English proficiency rating scale in college English teaching. Foreign Language Teaching, 39(4), 1-4.

Zeng, Y. Q. (2017). Principles and methods for the establishment of the reading scale of the Chinese English proficiency rating scale. Foreign Languages, (5), 2-11. 